\title{
Justice and the Politics of Difference
}

\section{Iris Marion Young}

With A NEW FOREWORD BY DANIELle AlleN

PRINCETON UNIVERSITY PRESS

PRINCETON AND OXFORD 
Copyright ( 1990 by Princeton University Press

Foreword to the 2011 edition copyright $@ 2011$ by Princeton University Press

Published by Princeton University Press, 41 William Street,

Princeton, New Jersey 08540

In the United Kingdom: Princeton University Press, 6 Oxford Street,

Woodstock, Oxfordshire OX20 1TW

press.princeton.edu

All Rights Reserved

First printing, 1990

Paperback reissue, with a new foreword by Danielle Allen, 2011

Library of Congress Control Number: 2011925684

ISBN: 978-0-691-15262-2

British Library Cataloging-in-Publication Data is available

This book has been composed in Linotron Caledonia

Printed on acid-free paper. $\infty$

Printed in the United States of America

$\begin{array}{llllllllll}10 & 9 & 8 & 7 & 6 & 5 & 4 & 3 & 2 & 1\end{array}$ 
For Dave 
